\title{
CONTENTS AND STRUCTURE OF INFORMATION- ANALYTICAL COMPETENCES OF USERS OF EDUCATIONAL INFORMATION SYSTEM: METHODOLOGICAL ASPECT
}

\section{ЗМІСТ ТА СТРУКТУРА ІНФОРМАЦІЙНО- АНАЛІТИЧНИХ КОМПЕТЕНТНОСТЕЙ КОРИСТУВАЧІВ ОСВІТНІХ ІНФОРМАЦІЙНИХ СИСТЕМ: МЕТОДОЛОГІЧНИЙ АСПЕКТ}

\author{
Valerii HRYTSENKO, \\ Candidate of Pedagogical Sciences, \\ Валерій ГРИЦЕНКО, \\ кандидат педагогічних наук, доцент \\ Associate Professor \\ https://orcid.org/0000-0001-5881-3491 \\ grycenko@ukr.net \\ Anna TKACHENKO, \\ АнНа ТКАЧЕНКО, \\ Candidate of Pedagogical Sciences, \\ Associate Professor \\ кандидат педагогічних наук, доцент \\ https://orcid.org/0000-0002-5326-1840 \\ avtkachenko7@ukr.net \\ Bohdan Khmelnitsky National \\ University at Cherkasy \\ 81 Shevchenko Boulevard, \\ Cherkasy, 18000 \\ Original manuscript received: October 04, 2019
}

Revised manuscript accepted: December 11, 2019

\section{ABSTRACT}

The article deals with the theoretical and methodological bases of forming information and analytical competences for users of educational information systems. It has been found out that increasing the role and level of using information and communication technologies in the management of a modern university for effective solution of real managerial, scientific, technical, socio-economic problems arising in this sphere of activity is among the unresolved topical tasks of restructuring the processes in higher education management. We have established that a competent approach is a modern benchmark of the national education system of Ukraine according to the current trends in the development of university education. In order to implement a competencybased approach, it is necessary to extrapolate its basic ideas to the entire educational process at university, including the management component. As the competence approach is the conceptual basis for updating the content of future specialists training with higher education to work in today's society, it is important to clarify the conceptual and categorical aspect of the outlined problem. On the basis of the literary sources 
Серія: Педагогічні науки. - Вип.3. - Бердянськ : БДПУ, 2019. - 453 с.

analysis the main functions of the competence approach in education are distinguished: operational; activity-technological; organizational; diagnostic; as well as the content of the following concepts: On the basis of the literary sources analysis the main functions of the competence approach in education are distinguished: operational; activitytechnological; organizational; diagnostic; as well as the content of the following concepts: 1) "information and analytical competence of users (academic staff of universities) educational in formation systems"; 2) "information and analytical competence of university students". The first is presented as a complex characteristic that reflects their awareness of effective methods of finding, collecting, analyzing and processing data for solving professional problems by means of information and communication technologies in the conditions of constant changes the information educational and scientific environment in the higher education institutions.

The second one is a complex characteristic, reflecting their awareness of the latest information technologies and the ability to productively create their own educational environment by isolating, integrating and adapting various types of software and technologies of educational and social orientation for education needs.

Key words: competence approach, information-analytical competence, users of educational information systems at university.

Вступ. Сучасна вища школа України не може залишатися осторонь від процесів модернізації освіти, що відбуваються нині в усьому світі. Її стосуються всі світові тенденції та інновації: особистісно-зорієнтований підхід, інформатизація, інтеграція тощо. До них належить і компетентнісний підхід, поява якого пов'язана, насамперед, з кризовими явищами та процесами в освіті, що полягають у протиріччі між програмними вимогами до майбутнього фахівця, запитами суспільства і потребами самої особистості в освіті. Ідея компетентнісного підходу - одна із відповідей на запитання про те, який результат освіти необхідний особистості і затребуваний сучасним суспільством: навчити навчатися і виробити потребу в навчанні упродовж життя. Формування компетентного фахівця на сьогоднішній день $€$ однією із нагальних проблем освіти, котра актуалізує важливу функцію освітнього процесу - навчити людину використовувати отримані знання у своїй практичній діяльності професійній, громадсько-політичній, побутовій тощо і може розглядатися як один із можливих шляхів розв'язання зазначеної проблемної ситуації, що виникла через протиріччя між необхідністю забезпечити якість освіти та неможливістю вирішити цю проблему традиційним шляхом.

Ще однією з невирішених актуальних задач перебудови процесів управління вищої освіти в сучасних умовах $€$ підвищення ролі та рівня використання інформаційно-комунікаційних технологій в управлінні сучасним університетом для ефективного розв'язання реальних управлінських, науково-технічних, соціально-економічних задач, що виникають у цій сфері діяльності людини.

Методи та методики дослідження: теоретичні: аналіз, узагальнення, систематизація результатів наукових досліджень 3 проблеми дослідження; синтез наявних підходів до процесу формування інформаційно-аналітичної компетентності користувачів освітніх інформаційних систем; педагогічне моделювання процесу формування та 
розвитку інформаційно-аналітичної компетентності користувачів освітніх інфрормаційних систем на засадах компетентнісного підходу.

Результати та дискусії. Компетентнісний підхід до освітнього процесу в закладах вищої освіти (ЗВО) на сьогодні став найбільш актуальним через його прикладне спрямування та значну прагматичність. Формулювання результатів освітньої діяльності у формі компетентностей відповідає сучасній тенденції вищої освіти - формування фрахівця, конкурентоздатного на ринку праці, компетентного, який $€$ висококваліфікованим у своїй галузі та орієнтується в суміжних галузях діяльності, здатного до постійного професійного росту, соціальної та профресійної мобільності. Активними пошуками відповіді на питання про ефективне впровадження компетентнісного підходу як основи нової освітньої парадигми займались i продовжують напрацювання в зазначеному руслі як зарубіжні, так і вітчизняні дослідники. Зокрема, дослідник А. Андрєєв [Андрєєв, 2005] зазначає, що важливо формувати в майбутнього спеціаліста саме здатності отримувати знання, використовувати їх на практиці, виконувати ефективно певні професійні і соціальні функції. У роботах О. Заболоцької [Заболоцька, 2008] здійснено ґрунтовне дослідження компетентнісного підходу як сучасної освітньої інновації, проведено порівняльний аналіз компетентнісного підходу в навчанні $з$ традиційним та показано, що він $€$ інструментарієм для визначення результативно-цільової спрямованості освіти, що, на нашу думку, $€$ важливою перевагою його над іншими підходами в освіті. Дослідник О. Гулай [Гулай, 2009] наголошує на потребі побудови освіти, орієнтованої на формування i розвиток у молоді навичок життя в інфрормаційному суспільстві, що передбачає процес i результат прогнозування та формування людських рис, відношень, стилю діяльності людей і співтовариств, рис особистості, компетентностей, які забезпечують постійне підвищення якості життя. Варто виокремити також ідеї науковців В. Журавльова та В. Балашова, які ми цілком підтримуємо і розвиваємо, про те, що важливим завданням сьогодення, котре, як ніколи, наразі гостро постає - осмислення й пізнання буття, створення нової фрілософії освіти, відкритої до таємниць життя людини, її прагнень, життєвого потенціал, а саме тому має формуватися нова тенденція розвитку освіти 21 сторіччя освіта для формування компетентної, відповідальної особистості, яка передбачає як важливу складову власне компетентне ставлення особистості до життя.

Узагальнюючи огляд літературних джерел, можемо виокремити основні функції компетентнісного підходу в освіті [Хоружа, 2018]: операційна: виявлення системи знань, умінь, навичок, видів готовності, які визначають компетентність; діяльнісно-технологічна: конструювання змісту навчання з урахуванням майбутньої профресії; організаційна: формування ділових якостей, управлінського досвіду; діагностична: розробка системи моніторингу якості підготовки, сформованості компетентностей.

Проблема формування компетентностей особистості 
багатоаспектна, саме тому досить широко і ґрунтовно представлена у вітчизняних та зарубіжних дослідженнях. На основі аналізу наукових джерел ми дійшли висновку, що сутнісною ознакою запровадження компетентнісного підходу в освіті $\epsilon$ : формування і розвиток компетентностей; можливість побачити результат освітнього процесу 3 позиції запитів суспільства, потреб ринку праці; цільова орієнтація освіти; спрямованість на результат у діяльнісному вимірі; активізація суб'єктності в навчанні; технологічність (створення умов для активної соціальної дії, проєктної, дослідницької діяльності) [Хоружа, 2018].

Отже, компетентнісний підхід - це сучасний орієнтир національної системи освіти України, для реалізації якого потрібна екстраполяція його основних ідей на увесь освітній процес ЗВО. Оскільки компетентнісний підхід $€$ концептуальною основою оновлення змісту підготовки майбутніх фахівців з вищою освітою до роботи в умовах сучасного суспільства, важливо з'ясувати понятійно-категоріальний аспект окресленої проблеми.

У наукових джерелах компетентність визначається як специфічна динамічна категорія, що характеризує людину як суб'єкт діяльності, її здатність успішно виконувати свої повноваження у тій чи іншій професійній сфері; виражається через знання, розуміння, уміння, цінності, інші якості особистості [Хоружа, 2018]. Існують різні погляди та тлумачення змісту дефініції “компетентність”. Результати аналізу наукових праць свідчать про те, що питання визначення особливостей, структури і змісту компетентності та її компонентів досить широко, різнопланово і ємнісно висвітлюються в науково-методичній літературі. Поняття компетентність походить від латинського терміна "competentia", що тлумачать як коло питань, у яких людина добре обізнана, має знання та досвід, тобто компетентна в певній сфері людина має відповідні знання, вміння, навички та здібності. Вони надають можливість їй обґрунтовано висловлювати власне бачення, що стосується питань у цій сфері й ефективно в ній діяти [Хуторской, 2009]. Зокрема, дослідник О. Гайдамак наголошуючи на особливості природи компетентності, переконує, що "вона може проявлятися тільки в органічній єдності з цінностями” [Гайдамак, 2006: 17], тобто має бути сформована глибока особистісна зацікавленість у певному виді діяльності; британський дослідник Дж. Равен [Равен, 2001] зазначає, що компетентність - це специфічна здатність, необхідна для ефективного виконання конкретної дії в певній предметній сорері, вміщує вузькоспеціальні знання, особливі предметні навички, засоби мислення, а також розуміння відповідальності за свої дії. На думку науковця О. Капітанця [Капітанець, 2001], компетентність $€$ загальною здатністю людини, що базується на знаннях, досвіді, цінностях, нахилах, набутих у процесі навчання. Досить змістовним та влучним видається трактування розглядуваної дефініції нормативним документом “Національною рамкою кваліфікацій” (НРК) [Національна рамка кваліфікацій, 2011: 15], у якій зазначено, що компетентність - це структурований спеціальним шляхом набір знань, умінь, навичок, спроможностей і ставлень, що дають змогу майбутньому фахівцю визначити, тобто ідентифікувати і вирішувати 
незалежно від контексту проблеми, характерні для певного напряму професійної діяльності.

У науково-педагогічних дослідженнях ми спостерігаємо намагання структурувати зміст поняття “компетентність", проте слід зазначити, що одностайності в поглядах дослідників не спостерігається, зокрема, частина науковців під компетентністю розуміє єдність когнітивного, предметнопрактичного й особистісного досвіду людини [Гриценко, 2019]; інші пропонують у їі структурі виділяти мотиваційний, змістовий та процесуальний компоненти [Гриценко, 2019]; значна кількість дослідників тлумачать означене поняття як оцінну динамічну категорію, що характеризує людину як суб'єкта діяльності, її здатність успішно виконувати свої повноваження у тій чи іншій професійній сфрері, i яка виражається через знання, розуміння, уміння, цінності, інші якості особистості; зарубіжні дослідники переважно визначають три основних елементи в структурі компетентності: 1) знання, 2) уміння і навички, 3) цінності (ставлення) [Овчарук, 2004: 17]; експерти програми "DeSeCo" вважають, що структура компетентності охоплює пізнавальні ставлення i практичні навички, цінності, емоції, поведінкові компоненти, знання і вміння [Овчарук, 2004: 10].

Визначальним орієнтиром переліку фахових компетентностей $\epsilon$ переважно узгоджена позиція соціуму в певній країні або регіоні, тобто для кожної сфрери діяльності фрахівця виокремлено нормативними документами певний набір компетентностей, а інтегрування зазначених вище підходів до визначення змісту поняття компетентності надає можливість стверджувати про те, що структурними компонентами компетентності можна вважати знання, уміння й навички та здатності фахівця до професійної діяльності.

Розрізняють загальні компетентності, предметні, ключові та професійні. Так, наприклад, у Національній рамці кваліфікацій визначено загальні компетентності випускника університету, детально проаналізувавши які, можемо зазначити, що загальна компетентність це здатність особистості приймати рішення й нести відповідальність за їхню реалізацію в різних галузях людської діяльності, тобто зміст такого означення передбачає наявність у людини сукупності фізичних та інтелектуальних якостей і властивостей, необхідних їй для самостійного й ефективного виходу з різних життєвих ситуацій, щоб створити кращі умови для себе в конструктивній взаємодії з іншими. Таким чином, під загальною компетентністю будемо розуміти інтегровану характеристику якостей особистості і рівня їі підготовки до виконання фахово-орієнтованих завдань у професійній діяльності.

Нині вектор реформування національної системи освіти України спрямований у площину інформатизації суспільного життя й освіти 3 метою розбудови сучасного динамічного інформаційного суспільства та головне - входження до світового освітнього простору. Саме тому до сучасного університету висуваються вимоги підготовки майбутніх фахівців на засадах компетентнісного підходу, розвитку дослідницьких, 
комунікативних і професійних компетентностей, творчих здібностей особистості, системного запровадження новітніх інформаційнокомунікаційних технологій тощо. Слушною тут $\epsilon$ думка науковця Л. Панченко [Панченко, 2006], яка зауважує, що запровадження засобів IКT у освітній процес буде ефективним, якщо воно матиме супровід у фрормі підготовки викладачів та студентів до взаємодії й співпраці в інформаційно-освітньому середовищі університету.

3 огляду на зазначене, актуальним наразі видається формування саме інформаційно-аналітичних компетентностей (ІАК) у студентів та науково-педагогічних працівників університетів. Тому $є$ потреба здійснити аналіз фрілософських, психологічних, педагогічних трактувань понять, що дозволить виокремити важливі для подальшого дослідження етапи, методичні прийоми та засоби формування і розвитку IAK у студентів та науково-педагогічних працівників університетів.

Аналіз змісту поняття "інформаційно-аналітична компетентність" у наукових працях вітчизняних $\mathrm{i}$ зарубіжних дослідників дає підстави стверджувати, що донині не знайдено єдиного підходу до його тлумачення та структурних елементів. Дослідник Н. Баловсяк [Баловсяк, 2006] ІАК розглядає як сукупність компетенцій, пов'язаних із опрацюванням даних у всіх їхніх формах і поданнях, які надають можливість ефрективно використовувати інформаційні технології різних видів як у традиційній друкованій формі, так і з використанням комп'ютерних телекомунікацій, працювати з відомостями й даними в різних їхніх формах і поданнях у повсякденному житті й професійній діяльності, виокремлюючи три основних компоненти, що $\epsilon$ важливими для ії фрормування: 1) інформаційний компонент - ефективне використання відомостей у всіх формах їхнього представлення, які цікавлять конкретну людину в конкретній ситуації; 2) комп'ютерний або комп'ютерно-технологічний компонент, що складається з уміння користуватися інформаційними технологіями, працювати на комп'ютері, використовувати різноманітне програмне забезпечення; 3) процесуально-діяльнісний компонент- здатність застосовувати інформаційні, комп'ютерні та Інтернет-технології для роботи 3 інформаційними ресурсами [Баловсяк, 2006].

Дослідник А. Хуторський тлумачить “компетентність" у певній галузі як володіння відповідними знаннями та здібностями, які дають змогу ґрунтовно судити про цю галузь та ефективно діяти в ній [Хуторской, 2009]. На думку науковця Л. Петренко, інформаційно-аналітичну компетентність слід розглядати і як явище, і як процес, оскільки у цьому випадку зберігатимуться іiї властивості: дуальність, цілісність та поліфункціональність [Петренко, 2012]. У дослідженнях О. Гайдамак ІАК розглядається як готовність до розв'язання професійних завдань за допомогою інформаційнокомунікативних технологій на основі семантичного опрацювання даних в умовах швидких змін інформаційного середовища, а також наголошується, що інформаційно-аналітична компетентність пронизує всі інші види компетентності в складі профресійної (у зв'язку з фундаментальністю понять “інформація" і "аналіз") і є умовою їхнього вдосконалення, спрямованою на 
самостійне опанування професійною майстерністю, передумовою розвитку науково-дослідної діяльності, містить у собі механізми, які надають можливість ефективно розв'язувати професійно-педагогічні завдання, спираючись на використання інформаційно-комунікативні технології і семантичне опрацювання даних [Гайдамак, 2001]. Досить коректним $\epsilon$ розуміння змісту ІАК дослідником М. Фоміним, який зазначає, що інформаційно-аналітична компетентність майбутнього фахівця - це структурна складова його професійної компетентності, що визначається як готовність до ефективного розв'язання професійних завдань в умовах невизначеності (неповної інформації) [Фомин, 2009]. Згідно з поглядами дослідниці Н. Лобач інформаційно-аналітична компетентність забезпечує реалізацію основних важливих функцій професійної діяльності майбутнього фахівця: 1) гностичної - засвоєння знань, необхідних для планування, організації та керування освітньою, а в подальшому - i профресійною діяльністю; 2) діяльнісної - формування вмінь застосовувати отриманні знання в практичній діяльності; 3) інформаційно-комунікативної - активізація взаємодії 3 різними джерелами інформації, що сприяє адаптації до динамічного інфрормаційного середовища, розвитку вміння чітко та зрозуміло формулювати думки; 4) аналітико-конструктивної - оволодіння знаннями, необхідними для виконання інформаційно-аналітичної діяльності; 5) цінніснорефлексійної - формування ціннісного відношення до інформації, самодіагностика інформаційно-аналітичної компетентності та прагнення до самовдосконалення як майбутнього фахівця [Лобач, 2016: 35].

Під інформаційно-аналітичною компетентністю користувачів (науково-педагогічних працівників університетів) освітніх інформаційних систем ми будемо розуміти комплексну характеристику, що відображає їх обізнаність щодо ефективних методів пошуку, збирання, аналізу й опрацювання даних та здатність продуктивно використовувати ці методи для розв'язування професійних задач за допомогою засобів інформаційно-комунікаційних технологій в умовах постійних змін інформаційного освітньо-наукового середовища закладу вищої освіти.

Стосовно змісту поняття "інформаційно-аналітична компетентність" відносно студентів університету, які є одними з основних користувачів освітньої інформаційно-аналітичної системи управління університетом, незважаючи на численні й змістовні дослідження науковців, можемо уточнити: ІАК студентів - це комплексна характеристика, що відображає їхню обізнаність 3 новітніми інформаційними технологіями і здатність до продуктивного утворення власного освітнього середовища шляхом виокремлення, інтеграції й адаптації різного роду програмних засобів та технологій освітнього і соціального спрямування задля реалізації власних освітніх потреб.

На основі аналізу психолого-педагогічної літератури нами виокремлено структурні компоненти (когнітивний, діяльнісний та особистісний) і показники, що відповідають рівням сформованості ІАК (початковий, середній, достатній, високий) користувачів інформаційних систем. 
Когнітивний компонент: відповідає за рівень сформованості теоретичного й технологічного складників ІАК. Його показниками визначається: обізнаність та здатність демонструвати розуміння фундаментальних професійно орієнтованих принципів, що відповідають певній професійній діяльності; готовність та здатність застосовувати знання для ідентифікації, фрормулювання та вирішення окреслених сферою діяльності фахівця проблем, використовуючи притаманні цій сфрері методи; обізнаність з методологіями проєктування об'єктів із власної сфери професійної діяльності, готовність демонструвати їх розуміння та здатність використовувати на практиці; уміння аналізувати й синтезувати, креативно й логічно мислити.

Діяльнісний компонент: відповідає за рівень сформованості окремих практично орієнтованих професійних компетентностей, спрямованих на професійну самореалізацію. Його показниками визначається здатність: інтегрувати теорію і практику для вирішення проблем фахового спрямування; використовувати сучасні засоби фахового призначення; здійснювати пошук відомостей і даних з різних джерел, їхнє опрацювання й аналіз для фрахових потреб; розробляти й описувати процедуру вирішення проблем фахового спрямування, вибирати та використовувати для цього відповідні методи та засоби; до ефективної роботи в команді.

Особистісний компонент: відповідає за рівень сформованості мотиваційного, комунікаційного складників особистісних професійнозначущих якостей. Його показниками визначається: готовність і здатність навчатися й самонавчатися; здатність розпізнавати власні освітні потреби; готовність і здатність усвідомлювати особисту відповідальність за прийняті рішення; здатність до міжособистісної взаємодії в умовах командної роботи.

Висновки. У результаті проведеного дослідження 3 позицій компетентнісного підходу з'ясовано, що ІАК користувачів (студентів та науково-педагогічних працівників) освітніх інформаційних систем у закладах вищої освіти $є$ складною багатокомпонентною категорією, формування і розвиток якої вимагає розробки відповідних методичних підходів, методів та засобів, які б сприяли ефективній організації освітнього процесу в ЗВО та реалізації компетентнісної освіти в суб'єктів освітньої діяльності 3 дотриманням дидактичних умов поєднання традиційних та інноваційних освітніх технологій.

\section{Література}

1. Андреев А. Л. Компетентносная парадигма в образовании: опыт философрско-методологического анализа. Педагогіка. 2005. № 4. С.19-27.

2. Заболоцька О.С. Компетентнісний підхід як освітня інновація: порівняльний аналіз. Вісник Житомирського державного університету. Серія: педагогічні науки. 2008. Вип. 40. С.63-68.

3. Гулай О. І. Компетентнісний підхід як основа нової парадигми освіти. Вісник Національної академії Державної прикордонної служби України. Серія: педагогічні науки. 2009. Вип. 2. С.41-48.

4. Хоружа Л. Л. Теоретичні аспекти впровадження компетентнісного підходу у вищу освіту. Київський університет імені Бориса Грінченка. URL: 


\section{Наукові записки БДПУ (http://bdpu.org/pedagogy/ua/)}

http://kubg.edu.ua/images/stories/Departaments/horuzall.pdf (дата звернення: 09.04.2018).

5. Хуторской А. В. Ключові освітні компетентності. Освіта.иа. 2009. URL: http://osvita.ua/school/method/2340/ (дата звернення: 08.05.2018).

6. Гайдамак Е. С. Развитие информационно-аналитической компетентности в процессе разработки электронных средств учебного назначения. Вестник Омского государственного педагогического. универсuтemama. 2006. URL: www.omsk.edu (дата обащения: 07.05.2018).

7. Равен Дж. Педагогическое тестирование проблемы, заблуждения, перспективы: пер. с англ. Москва, 2001. - 142 с.

8. Капітанець О. М. Педагогічна підготовка менеджерів у вищих технічних навчальних закладах: дис. ... канд. пед. наук: 13.00.04. Вінниця, 2001. - 211 с.

9. Про затвердження Національної рамки кваліфікацій: постанова Кабінету Міністрів України від 23.11.2011p. № $1341 . \quad$ URL: http://zakon0.rada.gov.ua/laws/show/1341-2011-\%D0\%BF (дата звернення: 08.05.2018).

10. Компетентнісний підхід у сучасній освіті: світовий досвід та українські перспективи / за заг. ред. О. В. Овчарук. Київ: К.І.С., 2004. -112 с.

11. Гриценко В.Г. Теоретико-методичні основи проектування та впровадження інформаційно-аналітичної системи управління університетом: дис. ... доктора педагогічних наук: 13.00.10 -інформаційно-комунікаційні технології в освіті (01 Освіта / Педагогіка»). Київ, 2019. - 623 с.

12. Панченко Л. Ф. До питання розвитку інформаційно-освітнього середовища. Інформаційні технології в наукових дослідженнях $і$ навчальному процесі: матеріали II Міжнар. наук.-практ. конф. (м. Луганськ, 14-16 листоп. 2006 р.). Луганськ: Альма-матер, 2006.- Т. 2. - С. 52-54.

13. Баловсяк Н. В. Формування інформаційної компетентності майбутнього економіста в процесі професійної підготовки: автореф. дис. на здобуття наук. ступеня кандидата пед. наук. Київ, 2006. - 25 с.

14. Петренко Л. Інформаційно-аналітична компетентність керівників професійно-технічних навчальних закладів як соціально-педагогічна проблема. Проблеми підготовки сучасного вчителя: зб. наук. праць Уманського держ. пед. ун-ту імені Павла Тичини / ред. кол.: Побірченко Н. С. (гол. ред.) та ін. Умань: ПП Жовтий О. О., 2012.- Вип. 5. -Ч. 2. - С. 180-187.

15. Фомин В.И. Развитие содержания подготовки к информационноаналитической деятельности на основе семиотического подхода: дис. ... доктора пед. наук: 13.00.02. - Самара, 2009. - 385 с.

16. Лобач Н. В. Формування інформаційно-аналітичної компетентності майбутніх лікарів в освітньому середовищі вищого медичного навчального закладу: дис. ... канд. пед. наук. Полтава, 2016. - 234 с.

\section{References}

1. Andreev A. (2005). Kompetentnosnaya paradigma $v$ obrazovanii: opyt filosofsko-metodologicheskogo analiza [Competent paradigm in education: the experience of philosophical and methodological analysis], Pedagogika, 19-27 [in Ukrainian].

2. Zabolocz ka O. (2008) Kompetentnisny`j pidxid yak osvitnya innovaciya: porivnyal'ny j analiz [Competency approach as educational innovation: A comparative analysis], Visny`k Zhy`tomy`rs`kogo derzhavnogo universy`tetu, 63-68 [in Ukrainian].

3. Gulaj O. (2009). Kompetentnisny`j pidxid yak osnova novoyi parady gmy osvity ' Competency approach as the basis of a new paradigm of education], Visny'k Nacional’noyi akademiyi Derzhavnoyi pry`kordonnoyi sluzhby` Ukrayiny`,41-48 [in Ukrainian]. 
4. Xoruzha L. (2018). Teorety`chni aspekty`vprovadzhennya kompetentnisnogo pidxodu u vy'shhu osvitu [Theoretical aspects of implementation of the competence approach in higher education], Ky`yivs`ky`j universy`tet imeni Bory`sa GrinchenkaURL: http :// kubg. edu.ua/images/stories /Departaments /horuzall.pdf [in Ukrainian].

5. Xutorskoj A. (2018). Klyuchovi osvitni kompetentnosti [Key educational competences], URL: http://osvita.ua/school/method/2340/ [in Ukrainian].

6. Gajdamak E. (2018). Razvy`ty`e y`nformacy`onno-analy`ty`cheskoj kompetentnosty` $v$ processe razrabotky` эlektronnыx sredstv uchebnogo naznacheny`ya [The development of information and analytical competence in the process of developing electronic educational tools], Vestny`k Omskogo gosudarstvennogo pedagogy cheskogo. uny versy`tetata. URL: www.omsk.edu [in Russian].

7. Raven Dzh. (2001). Pedagogicheskoe testirovanie problemy, zabluzhdeniya, perspektivy [Pedagogical testing of the problem, misconceptions, prospects], Moskva, «Kogito-Centr» [in Russian].

8. Kapitanecz` O. (2001). Pedagogichna pidgotovka menedzheriv u vy`shhy`x texnichny`x navchal'ny'x zakladax [Pedagogical Training of Managers in Higher Technical Institutions], Vinny cya, Vinny`cz`ky j derzh. texnichny`j unt. [in Ukrainian].

9. Kabinetu Ministriv Ukrayiny` (2018). Pro zatverdzhennya Nacional 'noyi ramky` kvalifikacij: postanova vid 23.11.2011r. \# 1341 [On approval of the National Qualifications Framework: Resolution of the Cabinet of Ministers of Ukraine dated 23.11.2011. № 1341.], URL: http://zakon0.rada.gov.ua/laws/show/1341-2011-\%D0\%BF [in Ukrainian].

10. Ovcharuk O. (2004). Kompetentnisny j pidxid u suchasnij osviti [Competent Approach in Modern Education], svitovy`j dosvid ta ukrayins`ki perspekty`vy`, Ky`yiv, K.I.S. [in Ukrainian].

11. Hrytsenko V. (2019). Teoretyko-metodychni osnovy proektuvannia ta vprovadzhennia informatsiino-analitychnoi systemy upravlinnia universytetom [Theoretical and Methodological Foundations of Designing and Putting into Operation the Information-Analytical System of University Management], dys. ... doktora pedahohichnykh nauk: 13.00.10 -informatsiino-komunikatsiini tekhnolohii $v$ osviti (01«Osvita / Pedahohika»). Kyiv. [in Ukrainian].

12. Panchenko L. (2006). Do py`tannya rozvy`tku informacijno-osvitn`ogo seredovy shha [On the development of information and educational environment], Informacijni texnologiyi v naukovy`x doslidzhennyax i navchal'nomu procesi, Lugans'k: Al`ma-mater. [in Ukrainian].

13. Balovsyak N. (2006). Formuvannya informacijnoyi kompetentnosti majbutn`ogo ekonomista $v$ procesi profesijnoyi pidgotovky [Formation of information competence of the future economist in the process of vocational training], Ky yiv. [in Ukrainian].

14. Petrenko L. (2012). Informacijno-anality’chna kompetentnist` kerivny`kiv profesijno-texnichny`x navchal'ny'x zakladiv yak social'no-pedagogichna problema [Information-analytical competence of heads of vocational schools as a socialpedagogical problem], Problemy` pidgotovky` suchasnogo vchy`telya, Uman`, PP Zhovty j O.O. [in Ukrainian].

15. Fomy`n V. (2009). Razvy`y`e soderzhany`ya podgotovky k y`nformacy`onno-analy ty`cheskoj deyatel'nosty` na osnove semy`oty cheskogo podxoda [Development of the content of preparation for informational and analytical activities based on the semiotic approach], Samara. [in Russian].

16. Lobach N. (2016). Formuvannya informacijno-anality`chnoyi kompetentnosti majbutnix likariv $v$ osvitn`omu seredovy`shhi vy`shhogo medy`chnogo navchal'nogo zakladu [Formation of information and analytical competence of future physicians in the educational environment of a higher medical institution], Poltava [in Ukrainian]. 


\begin{abstract}
АНОТАЦІЯ
У статті розглянуто теоретико-методологічні основи фрормування інфрормаційно-аналітичних компетентностей у користувачів освітніх інфрормаційних систем. З'ясовано, що серед невирішених актуальних задач перебудови процесів управління вищої освіти в сучасних умовах є підвищення ролі та рівня використання інформаційно-комунікаційних технологій в управлінні сучасним університетом для ефективного розв'язання реальних управлінських, науковотехнічних, соціально-економічних задач, що виникають у иій сфрері діяльності. 3 огляду на сучасні тенденції розвитку університетської освіти нами встановлено, що компетентнісний підхід - це сучасний орієнтир національної системи освіти України. Для реалізації компетентнісного підходу потрібна екстраполяція його основних ідей на увесь освітній процес ЗВО, зокрема й на управлінську складову. Оскільки компетентнісний підхід є концептуальною основою оновлення змісту підготовки майбутніх фрахівців з вищою освітою до роботи в умовах сучасного суспільства, тому важливо з'ясувати понятійно-категоріальний аспект окресленої проблеми. На основі аналізу літературних джерел виокремлено основні функції компетентнісного підходу в освіті: операційна; діяльнісно-технологічна; організаційна; діагностична; а також уточнено зміст понять 1) “інформаційноаналітична компетентність користувачів (науково-педагогічних працівників університетів) освітніх інформаційних систем" - це комплексна характеристика, що відображає їх обізнаність щодо ефективних методів пошуку, збирання, аналізу й опрацювання даних та здатність продуктивно використовувати ці методи для розв'язування профресійних задач за допомогою засобів інформаційно-комунікаційних технологій в умовах постійних змін інформаційного освітньо-наукового середовища закладу вищої освіти; 2) “інформаційно-аналітична компетентність студентів університету" - це комплексна характеристика, що відображає їхню обізнаність з новітніми інформаційними технологіями і здатність до продуктивного утворення власного освітнього середовища иляхом виокремлення, інтеграції й адаптації різного роду програмних засобів та технологій освітнього $і$ соціального спрямування задля реалізації власних освітніх потреб.
\end{abstract}

Ключові слова: компетентнісний підхід, інфоормаційно-аналітична компетентність, користувачі освітніх інфрормаційних систем в університеті. 